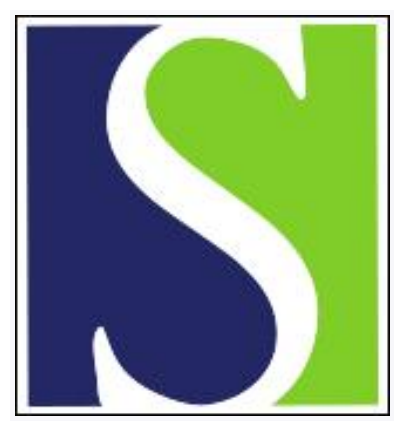

Scand J Work Environ Health 2009;35(4):241-243

https://doi.org/10.5271/sjweh.1336

Issue date: 31 Jul 2009

The importance of the psychosocial work environment for employee well-being and work motivation

by Sverke $M$

Affiliation: Department of Psychology, Stockholm University, Stockholm, Sweden, magnus.sverke@psychology.su.se

Refers to the following texts of the Journal: 2008;34(4):260-266

2008;34(6):430-437 2009;35(2):85-95 2008;34(5):345-355

2006;32(6):493-501 2006;32(6):443-462 2009;35(4):284-293

2009;35(4):294-300 2001;27(3):161-213

Key terms: editorial; employee well-being; motivation; psychosocial work environment; well-being; work environment; work motivation

This article in PubMed: www.ncbi.nlm.nih.gov/pubmed/19562234 


\section{The importance of the psychosocial work environment for employee well-being and work motivation}

The issue of the psychosocial work environment has long been of central interest to research on workers' health and safety as well as employee motivation and performance. Several conceptualizations of work climate perceptions have been developed over the years. One classic application is Karasek's demandcontrol model (1), to which social support was later added (2); the resulting demand-control-support model (3) has been used frequently in occupational health research. An alternative model, which distinguishes between a broader range of job demands and a variety of resources at work, is the demandsresources model (4). Siegrist's effort-reward imbalance model (5), highlighting both job content and the work role in a broader social perspective, is another model which has attracted growing attention. Models that place a special emphasis on positive factors in the work environment include Hackman \& Oldham's job characteristics model (6), James \& Sell's psychological climate model (7), and Warr's vitamin model (8). Several decades of research have contributed to the identification of psychosocial work characteristics that are detrimental to employee health and well-being and others that may lead to meaningfulness at work.

The Scandinavian Journal of Work, Environment \& Health has played an important role in this development. Articles have been published on issues such as the potential effect of work conditions on sickness absence (9) and return-to-work after long-term sick leave (10). Other studies have shed light on gender differences in psychosocial factors (11) or investigated how favorable work conditions may promote dedication at work and mitigate the negative impact of job demands on musculoskeletal disorders (12). The journal has also published narrative reviews (13) and meta-analytic studies (14) that have made important contributions to the literature. It is by now well-known that factors such as too high job demands, role conflict, job insecurity, time pressure, violence at work, poor leadership, and excessive work hours may negatively affect the individual employee. On the other hand, several beneficial factors have also been identified, including control at work, participation in decision-making, social support, clear goals, relevant feedback, and skill utilization.

Given the importance of psychosocial work conditions for employee health and well-being, the search for the so-called "good work" is not surprising (15). Although such efforts have been made throughout the industrial world, it could be claimed that the Scandinavian countries have played a central role in this respect. Labor legislation has aimed at reducing risks at work and improving the work climate. Scandinavian work environment research, by tradition, has emphasized the importance of employee job control and participation. Furthermore, trade unions have fought for better working conditions on behalf of their members, realizing that a positive work climate will not only reduce employee strain but also contribute to a more motivated workforce and, in the long run, greater organizational effectiveness.

In line with this reasoning, the 13th European Congress of Work and Organizational Psychology, which was held in Stockholm in 2007, emphasized the "win-win" of positive working conditions in the congress theme: "Sustainable Work: Promoting Human and Organizational Vitality". What comes as a surprise, however, is the indication from recent research that the psychosocial work environment may in fact be developing in a negative way - despite efforts to the contrary. Such a negative trend has been observed in the member countries of the Organization for Economic Cooperation and Development (OECD) (16), Europe (17), as well as in several specific countries.

This issue of the Scandinavian Journal of Work, Environment \& Health includes an important article by Pejtersen \& Kristensen (18). Using nationally representative survey data from the Danish working population 
(aged 20-60) in 1997 and 2005, the authors investigated differences between the two points in time. The Copenhagen Psychosocial Questionnaire was administered to both samples, which allowed for a comprehensive assessment of psychosocial work conditions. Although about half of the investigated psychosocial dimensions were found not to have differed significantly between the two periods, the authors found that the 2005 sample reported a higher work pace as compared to 1997. Role conflict, conflicts at work, threats of violence, and gossiping were also more pronounced in 2005 than in 1997. Moreover, employees' opportunities to exert influence and job control, possibilities for development at work, meaning of work, and sense of community were lower in 2005 than in 1997. The study also indicated that role clarity and social support from colleagues have developed in a negative way over these years. A striking characteristic of the study is that only two factors - social support from supervisors and quality of leadership - are found to have developed in a positive direction. These findings are to be understood in the light of the Scandinavian work environment tradition and the fact that Denmark, to quote the authors, " ... could be regarded as a 'best case' within the field of psychosocial work environment" (18, p.290).

There may be several potential explanations for the findings reported by Pejtersen \& Kristensen. One of the more optimistic ones, also discussed in the article, is that workers have become more aware of work environment problems and, hence, have come to demand more of their work situation. This is what Golembiewski et al (19), in their seminal article, termed gamma change. In short, gamma change refers to the fact that individuals reconceptualize what is meant by, for instance, influence at work and, as a result, would be likely to score lower on this phenomenon simply because they feel it would take more to feel that they have the possibility to actually influence their situation at work. While this could have been a desirable outcome of systematic work environment improvements or a function of media interest in work-related issues, the authors found no indications of gamma change in their data. It therefore seems plausible that the trends the authors found are indicative of a true development of working conditions in Denmark. Such a development would be in line with observations that we are witnessing a general intensification of work (20). Indeed, there is research to suggest that nowadays employees face new types of demands, such as emotional demands (21), and problems assessing whether their work is of high enough quality or even finished (22).

The problems stemming from impaired work conditions become even more pronounced in light of the consequences of negative psychosocial factors at work. Another relevant article in this issue - also from Denmark - is authored by Hannerz et al (23). The authors investigated to what extent mood disorders can be attributed to the work environment and, in this respect, build on recent research which suggests that impaired health and well-being indeed are likely to be a function of negative work characteristics. Whereas the number of articles addressing the link between work climate and mood disorders is limited, an interesting article, published in this journal in 2001, showed that a non-negligible portion of deaths related to depression could be traced back to negative work environment exposures (24). It has been suggested that the belief that work may affect one's health negatively may be not only detrimental in itself but also strengthen the negative impact of health complaints on work-related attitudes (25).

The psychosocial work environment thus again proves to be a significant factor for consideration. Pejtersen \& Kristensen make an important contribution to the literature by showing that work conditions appear to have become impaired, even in countries presupposed to have a strong work environment policy. Against this background, the findings of Hannerz et al - that mood disorders can partly be explained by work-related factors - become even more important. The message brought forward by these two articles is that impaired work conditions may not only be a work environment problem, but also that organizations and society at large may be losers in the long run. One of the major challenges for work environment research is to convince organizations that occupational health is a prerequisite for organizational growth and effectiveness. We need to find more effective ways of communicating our findings to management. There is ample evidence that organizational vitality is not possible without individual vitality - our major challenge is to make organizational management aware of this connection. 


\title{
References
}

1. Karasek RA. Job demands, job decision latitude and mental strain: Implications for job redesign. Adm Sci Q. 1979;24:285-307.

2. Johnson JV, Hall EM. Job strain, workplace social support and cardiovascular disease: a cross-sectional study of a random sample of the Swedish working population. Am J Public Health. 1988;78:1336-42.

3. Karasek RA, Theorell T. Healthy work. New York (NY): Basic Books; 1990.

4. Demerouti E, Bakker AB, Nachreiner F, Schaufeli WB. The job demands-resources model of burnout. J Appl Psychol. 2001;86:499-512.

5. Siegrist J. Adverse health effects of high-effort/low reward conditions. J Occup Health Psychol. 1996;1:27-41.

6. Hackman JR, Oldham GR. Development of the Job Diagnostic Survey. J Appl Psychol. 1975;60:159-70.

7. James, LR, Sells, SB. Psychological climate: theoretical perspectives and empirical research. In: Magnusson D, editor. Toward a psychology of situations: an interactional perspective. Hillsdale (NJ): Erlbaum; 1981. p 275-95.

8. Warr PB. A conceptual framework for the study of work and mental health. Work Stress. 1994;8:84-97.

9. Virtanen P, Siukola A, Luukkaala T, Savinainen M, Arola H, Nygård C-H, et al. Sick leaves in four factories - do characteristics of employees and work conditions explain differences in sickness absence between workplaces? Scand J Work Environ Health. 2008;34(4):260-6.

10. Josephson M, Heijbel B, Voss M, Alfredsson L, Vingård E. Influence of self-reported work conditions and health on full, partial and no return to work after long-term sickness absence. Scand J Work Environ Health. 2008;34(6):430-7.

11. Hooftman WE, van der Beek AJ, Bongers PM, van Mechelen W. Is there a gender difference in the effect of work-related physical and psychosocial risk factors on musculoskeletal symptoms and related sickness absence? Scand J Work Environ Health 2009;35(2):85-95.

12. Joling CI, Blatter BM, Ybema JF, Bongers PM. Can favorable psychosocial work conditions and high work dedication protect against the occurrence of work-related musculoskeletal disorders? Scand J Work Environ Health 2008;34(5):345-55.

13. Åkerstedt T. Psychosocial stress and impaired sleep [review]. Scand J Work Environ Health 2006;32(6, special issue):493-501.

14. Stansfeld S, Candy B. Psychosocial work environment and mental health - a meta-analytic review [review]. Scand J Work Environ Health 2006;32(6, special issue):443-62.

15. Gardner H, Csikszentmihalyi M, Damon W. Good work: when excellence and ethics meet. New York (NY): Basic Books; 2002.

16. Clark AE. Your money or your life: changing job quality in OECD countries. Br J Ind Relat. 2005;43:377-400.

17. Paoli P, Merllié D. Third European survey on working conditions 2000. Dublin: European Foundation for the Improvement of Living and Working Conditions; 2001.

18. Pejtersen JH, Kristensen TS. The development of the psychosocial work environment in Denmark from 1997 to 2005. Scand J Work Environ Health 2009;35(4):284-293.

19. Golembiewski RT, Billingsley K, Yeager S. Measuring change and persistence in human affairs: types of change generated by OD designs. J Appl Behav Sci. 1976;12:133-57.

20. Burchell BJ, Day D, Hudson M, Ladipo D, Mankelow R, Nolan JP, et al. Job insecurity and work intensification. York (United Kingdom): Joseph Rowntree Foundation; 1999.

21. van Vegchel N, de Jonge J, Söderfeldt M, Dormann C, Schaufeli W. Quantitative versus emotional demands among Swedish human service employees: moderating effects of job control and social support. Int J Stress Manage. 2004;11:21-40.

22. Hellgren J, Sverke M, Näswall K. Changing work roles: new demands and challenges. In: Näswall K, Hellgren J, Sverke M, editors. The individual in the changing working life. Cambridge (NY): Cambridge University Press; 2008. p 46-66.

23. Hannerz H, Tüchsen F, Holbaek Pedersen B, Dyreborg J, Rugulies R, et al. Work relatedness of mood disorders in Denmark. Scand J Work Environ Health 2009;35(4):294-300.

24. Nurminen M, Karjalainen A. Epidemiologic estimate of the proportion of fatalities related to occupational factors in Finland. Scand J Work Environ Health. 2001;27:161-213.

25. Göransson S, Näswall K, Sverke M. Work-related health attributions: their impact on work attitudes. Int J Workplace Health Manage. 2009;2:6-21.

\author{
Magnus Sverke \\ Department of Psychology \\ Stockholm University \\ Stockholm, Sweden \\ [Email: magnus.sverke@psychology.su.se]
}


